\title{
SELECTED ASPECTS OF BIOPHILOSOPHICAL CONTROVERSIES IN COMPLEX PLANT BEHAVIOUR RESEARCH
}

\begin{abstract}
We are currently witnessing changes in the scientific perception of the world of plants. Fundamental questions raised by scientists relate to the organization of plant life and concern the way in which signals are received from both the internal and external environment, and their acceptance or rejection depending on the potential consequences for the whole plant. The traditional understanding of plants as organisms devoid of sensual nature has undergone changes in favour of the conviction that advanced processes indicating intelligent plant behaviour could actually exist. The emergence of this new paradigm of research has triggered numerous disputes and controversies, both among scientists and philosophers.
\end{abstract}

Keywords: studies of plants, plant behaviour, plant intelligence, biophilosophical controversies

1. Introduction. 2. Traditional view of the plant world. 3. Changes in the understanding of plant functioning - a new paradigm? 4. Plant intelligence an empirically based biophilosophical controversy. 5. Conclusion.

\section{INTRODUCTION}

It is estimated that green plants comprise about $99 \%$ of the Earth's biomass. ${ }^{1}$ Nevertheless, throughout the ages plants have been perceived as passive creatures that exhibit only temporal and limited dynamics, which are the reactions to strong external stimuli. Because plants lack transparently noticeable dynamics of movement, to many

1 L.E. Rodin, N.I. Bazilevich, N.N. Rozov, Productivity of the World's Main Ecosystems, in: Productivity of World Ecosystems, eds. D.E. Reichle, et. al., National Academy of Science, Washington D.C 1975, 13-26, S. Mancuso, A. Viola, Brilliant Green. The Suprising History and Science of Plant Intelligence, Island Press, Washington 2015. 
they seemed devoid of any form of behaviour. One might gain the impression that the conflict between this rather common perception of plants and their adaptive success among living organisms has gone unnoticed.

Thanks to the increasing development of plant research, the view of plants as passive organisms is currently being replaced by exciting sensory and regulatory dynamics. Obviously, plants cannot choose to leave their place. Therefore their strategy to survive must differ from that of organisms able to move. We know that plants - as opposed to animals - have neither a brain nor a nervous and cardiovascular system. Nevertheless, for more than a decade various publications on plant intelligence and neurobiology have appeared. Many examples have shown that plants are "able" to predict, memorize, and evaluate their mistakes and to learn from them. ${ }^{2}$

Such a change in our understanding of the fundamental processes of plant functioning is taking place in front of our very eyes and has

2 See e.g.: M. Thellier et. al, Do memory processes occur also in plants?, Physiologia Plantarum 56(1982), 281-284; H. Knight et al, A history of stress alters drought calcium signalling pathways in Arabidopsis, Plant Journal 16(1998)6, 681-687; A. Trewavas, How plants learn, Proc. Natl. Acad. Sci. USA 96(1999), 4216-4218; Idem, Plant intelligence: Mindless mastery, Nature 415(2002), 841; Idem, Aspects of plant intelligence, Ann. Bot. 92(2003), 1-20; Idem, Aspects of plant intelligence: an answer to Firn, Ann. Bot. 93(2004), 353-357; Idem, Green plants as intelligent organisms, Trends Plant Sci. 10(2005a), 413-419; Idem, Plant intelligence, Naturwissenschaften 92(2005b), 401-413; Idem, Plant neurobiology - all metaphors have value, Trends Plant Sci. 12(2007), 231-233; Idem, Plant behaviour and intelligence, Oxford University Press, Oxford 2014; C.H. Goh et al., Stress memory in plants: a negative regulation of stomatal response and transient induction of rd22 gene to light in abscisic acid-entrained Arabidopsis plants, Plant J. 36(2003)2, 240-255; F. Cvrčková et al., Plant intelligence, Why, why not or where?, Plant Signaling \& Behavior 4(2009)5, 394-399; S. Karpiński, M. Szechyńska-Hebda, Secret life of plants. From memory to intelligence, Plant Signal. Behav. 5(2010).11, 1391-1394; Z. Starck, Roślina in vivo - kunszt funkcjonalności wzorowanej na procesach zachodzących u zwierząt, Wiad. Botan. 55(2011)1-2, 5-21; D. Chamovitz, What a plant knows. A Field Guide to the Senses, Scienific American/Farrar, Straus and Giroux, New York 2012; S. Mancuso, A. Viola, Brilliant Green. The Suprising History and Science of Plant Intelligence, Island Press, Washington 2015. 
resulted in the emergence of new scientific concepts of the organic world, which should be within the philosophers' sphere of interest. Both the theoretical assumptions based on empirical studies and the conclusions formulated within empirical research require philosophical reflection. Such a dynamically developing area of research is at present concerned with plant functioning within the context of the intelligent behaviour displayed by plants.

This article constitutes another attempt to trigger a discussion on the basic controversies at the foundation of the ambiguous and contentious concept of intelligent plant behaviour. The ongoing revived discussion presents us with very important questions concerning the line between sensual cognition and its absence in the world of living nature. Noticeable progress in research on plant behaviour indicates the necessity to change some of the previously derived conceptual results. Obviously, this article does not exhaust all the problematic aspects and is, as such, merely a contribution to further and more complex analysis of plant behaviour and the biophilosophical consequences of this new paradigm of research.

\section{TRADITIONAL VIEW OF THE PLANT WORLD}

In the western philosophical tradition, Aristotle conducted pioneering biological research focused on discovering the individual nature of animals and plants. Statements coming from his observations as well as philosophical generalizations led him to his tri-partite division of the living world. Aristotle based his statements concerning biological research on the concept of the vegetative soul, which he accepted to systematize and to causally explain the data, which come from direct observation of life. He argued for the existence of a "vegetative soul", which is an indivisible, non-quantitative factor that possesses the ability to form the "elements" of matter (air, water, fire and earth) into the "perfect" state reflecting our organism's generative form. According to Aristotle, all living organisms (i.e., 
plants, animals and humans) are equipped with a vegetative soul. In the case of plants a soul would be something individual, whereas for animals and humans it would be just a part (non-quantitative and non-spatial) of a dynamically richer factor explaining the creation of phenomena of a sensual and noetic cognition. Also, for Aristotle a vegetative soul was not a factor guiding the somewhat ready-made machinery of life; rather, it was a factor leading the process of its creation from the chaotic and relatively homogenous elements of matter. ${ }^{3}$ In Aristotle's opinion, plants were able to nourish, procreate and grow, but unlike animals they were devoid of a sensual nature. ${ }^{4}$

It should be emphasized that the Stagirite's approach to the world of plants fundamentally shaped botany. In subsequent ages, philosophers and researchers did not devote a lot of attention to the advanced behavior of plants, nor to their existential status within living nature.

Currently, science is gathering a wealth of empirical data on the elementary phenomena regarding plant life. New techniques allow us to conduct research employing non-invasive methods. At the centre of attention we find attempts to explain the mechanisms of regulation and the coordination of living processes at the genetic, molecular and organismal levels of organization, which is an attempt at the holistic conceptualization of plant functioning. ${ }^{5}$ Together with a better understanding of the dynamic behaviour of plants, the traditional Aristotelian conception of the boundaries of sensual processes came under questioning.

3 P. Lenartowicz, Elementy filozofii zjawiska biologicznego, WAM, Kraków 1986, 164; see e.g. D. Szkutnik, R. Kupczak, The Aristotelian concept of psyché trophica and contemporary attempts to conceptualize the functioning of plants holistically, Biocosmology - Neo-Aristotelism 5(2015)2, 186-195.

4 Aristotle, De Anima, , II, 414b II-415a 7, tr. by R.D. Hicks, https://archive.org/details/ aristotledeanima005947mbp [accessed: 11.07.2015].

5 See, e.g.: Plant Physiology, eds. L. Taiz, E. Zeiger, Sinauer Associates, Inc., Publ., Sunderland 1998; Fizjologia roślin, eds. J. Kopcewicz, S. Lewak, PWN, Warszawa 2002; Advances in Plant Physiology, ed. P.C. Trivedi, I K International Publishing House, New Delhi 2006. 


\section{CHANGES IN THE UNDERSTANDING OF PLANT FUNCTIONING - A NEW PARADIGM?}

Current research and plant observations have provided many interesting examples of complex adaptive behaviour. ${ }^{6}$ For instance, there are known examples of sprouts growing in a specific direction to avoid proximity with competing "neighbours". It is also known that the shape, height and direction of stem growth undergo changes to maintain an optimal position in relation to sunlight, and that leaves adjust their the position to optimize light reception. ${ }^{8}$ Plant rhizomes, which remoulded stalks growing underground (or underwater in

6 A. Trewavas, Plant intelligence: Mindless mastery, op. cit.; Idem, Green plants as intelligent organisms, op. cit., 413-419; Idem, Plant intelligence, op. cit., 401-413; Idem, Plant behaviour and intelligence, op. cit.; F. Baluška, S. Mancuso, D. Volkmann, P. Barlow, Root apices as plant command centres: the unique 'brain-like' status of the root apex transition zone, Biologia 59(2004)59/Suppl. 13, Bratislava, 7-19; F. Baluška, D. Volkmann, A. Hlavacka, S. Mancuso, P.W. Barlow, Neurobiological View of Plants and Their Body Plan, in: Communication in Plants: neuronal aspects of plant life, eds. F. Baluška, S. Mancuso, D. Volkmann, Springer, Berlin 2006, 19-35; Z. Starck Z., op. cit., 5-21.

$7 \mathrm{M}$. Franco, The influence of neighbours on the growth of modular organisms with an example from trees, Phil. Trans. R. Soc. Lond. Ser. B Biol. Sci. 313(1986), 209-225; M. Jones, J.L. Harper, The influence of neighbours on the growth of trees. I. The demography of buds in Betula pendula, Proceedings of the Royal Society London B 232(1987a), 1-8; M. Jones, J.L. Harper, The influence of neighbours on the growth of trees. II. The fate of buds on long and short shoots in Betula pendula, Proceedings of the Royal Society London B 232(1987b), 19-33.

8 G.M. Curry, Phototropism, in: The physiology of plant growth and development, ed. M.B. Wilkins, McGraw-Hill, London 1969, 243-273; P. Stoll, B. Schmid, Plant foraging and dynamic competition between branches of Pinus sylvestris in contrasting light environments, Journal of Ecology 86(1998)6, 934-945; E. Liscum, Phototropism: Mechanisms and Outcomes, Arabidopsis Book (2002), 1-21; C.W. Whippo, R.P. Hangarter, Phototropism: Bending towards Enlightenment, Plant Cell. 18(2006)5, 1110-1119; A. Goyal, B. Szarzynska, C. Fankhauser, Phototropism: at the crossroads of light-signaling pathways, Cell (2012), 1-9; J.M. Christie, A.S. Murphy, Shoot phototropism in higher plants: New light through old concept,. American Journal of Botany 100(2013)1, 35-46; I. Roig-Villanova, J.F. Martínez-García, Plant Responses to Vegetation Proximity: A Whole Life Avoiding Shade, Frontiers in Plant Science 7(2016), Article 236, 1-10. 
the case of aquatic plants), can choose to grow and retrieve food in places free from competitors and/or richer in resources. ${ }^{9}$ Roots can spatially follow the humidity and concentration of minerals in the soil and accelerate growth when they come across rich resources, but undertake oriented evasive actions when they approach a competitor's roots. When competing neighbours approach an open leaf, the whole plant just backs away thanks to diversification in the growth of root support assisting the stalk. ${ }^{10}$ Dodders (Cuscuta L.) parasitizes on other plants and do not carry out photosynthesis. The dodder haustoria surrounds appropriate providers and then it starts retrieving nutrients through them. If it attaches to a wrong provider, this is rejected within a few hours. But if the provider is accepted, then it decides about the number of haustoria for energy optimization on the basis of the energy that can be obtained from the provider in the following months. ${ }^{11}$ For Trewavas ${ }^{12}$ a dodder's behaviour corresponds

9 T.A. Bennet-Clark, N.G. Ball, The diageotropic behaviour of rhizomes, Journal of Experimental Botany 2(1951), 169-203; S.E. Mac Donald, V.J. Leiffers, Rhizome plasticity and clona foraging of Calamagrostis canadensis in response to habitat heterogeneity, J. Ecol. 81(1993), 769-776; E. Huber-Sannwald, D.A. Pryce, M.M. Caldwell, Perception of neighbouring plants by rhizomes and roots: morphological manifestations of a clonal plant, Can. J. Bot. 75(1997), 2146-2157.

10 J.E. Weaver, Root development of field crops, McGraw Hill, New York 1926, https:// soilandhealth.org/wpcontent/uploads/GoodBooks/Root\%20Development\%20of\%20 Field\%20Crops.pdf [accessed: 10.12.2015]; A.G. Salzman, Habitat selection in a clona plant, Science 228(1985), 603-604; K.D.M. McConnaughay, F.A. Bazzaz, Is physical space a soil resource, Ecology 72(1991), 94-103; K.D.M. McConnaughay, F.A. Bazzaz, The occupation and fragmentation of space:consequences of neighbouring roots, Functional Ecology 6(1992), 704-710; M.J. Hutchins, H. Kroon de, Foraging in plants: the role of morphological plasticity in resource acquisition, Advances in Ecological Research 25(1994), 159-238; J.P. Evans, M.L. Cain, A spatially explicit test of foraging behaviour in a clonal plant, Ecology 76(1995), 1147-1155; P.J. Gregory, Plant Roots: Growth, Activity and Interactions with the Soil, Wiley-Blackwell, Oxford 2006; G.G. McNickle1, J.F.Jr. Cahill, Plant root growth and the marginal value Thorem, PNAS 106(2009)12, 4747-4751.

11 C.K. Kelly, Resource choice in Cuscuta europea, Proc. Natl. Acad. Sci. U. S. A. 89(1992), 12194-12197. C.K. Kelly, Plant foraging: a marginal value model and coiling response in Cuscuta subinclusa, Ecology 71(1990), 1916-1925.

12 A. Trewavas, Green plants as intelligent organisms, op. cit. 
to the optimization model for acquiring food resources proposed by Charnov $^{13}$ for animals.

It is impossible to mention all the important examples of complex adaptive behaviour in plants here. What is significant is that thanks to the growing amount of scientific research, the necessity to assign some form of recognition (orientation) and free manipulation (within some limits) to plants can constitute the foundation of plant behaviour. It has been observed, for instance, that during the entire ontogenesis some processes are engaged in mutual cooperation at different levels of organization - from a single cell to the whole organism. The idea that the functionality of some plant mechanisms is as complex as that of animal organisms has appeared in the literature, and scientists started to question that possessing a nervous system is a necessary condition for the intelligent behaviour of living organisms. ${ }^{14}$ Trewavas ${ }^{15}$ claims that intelligence is not restricted to the brain and the nervous system, but has a more complex, multi-layered structure that applies to plants and that is overlooked by the majority of our scientific community.

It is assumed that the key premise, which is the core of the thesis about plant intelligence, is the belief that intelligent, plastic behaviour requires the precise coordination of actions from different structures. This requires the integration of signal information "transmitting" across the network of roots and sprouts. This imperative integrity of the whole organism must somehow be realized with the use of phenotypic and morphological functions as well as physiological plasticity. ${ }^{16}$ Research has shown that the integrity of an intercellular

13 E.L. Charnov, Optimal foraging, the marginal value theorem, Theoretical Population Biology 9(1976), 129-136.

14 Z. Strack, op. cit.

15 A. Trewavas, Aspects of plant intelligence, op. cit; Idem, Green plants as intelligent organisms, op. cit.; Idem, Plant intelligence, op. cit.; Idem, Plant behaviour and intelligence, op. cit.

16 E.g. A. Trewavas, Green plants as intelligent organisms, op. cit. 
signal is realized electrically, chemically and in part at the molecular level by long-distance electric transmission of signals, the production of chemical substances like neurotransmitters, the transport of auxins, and other plant hormones. ${ }^{17}$ Hence, it turns out that the key factor in the process regulation of plant growth and development is the overall exchange of information. This takes place at all levels of organization, from gene expression to biochemical reaction and cooperation between chloroplasts, mitochondria and other organelles as well as processes such as photosynthesis and respiration. ${ }^{18}$ The coordination of interdependent, sometimes opposing processes, such as the increase in water collection during droughts, the increased level of transpiration when a plant is water-logged, growth and dormancy, the creation of new cells, or their programmed death depends on the content of information. Coordination between processes is also essential, for instance, between photosynthesis and respiration, especially in circadian rhythms. Starck writes that "after a period of research with molecular biology as a dominant factor, in the centre of interest are now problems of the analysis of the whole organism's functioning, especially interaction between processes and organs." ${ }^{\prime 1}$.

As noted by Trewavas ${ }^{20}$, a typical plant comprises a network of millions of tissues and numerous meristems (regenerative tissue) interacting with each other. There is no obvious centralized tissue control and behaviour control resulting from cell and tissue systems integration here. Internally, plant cells and tissues communicate with each other using proteins, nucleic acids, hormones, as well as mineral, chemical, hydraulic,

17 See e.g.: E.D. Brenner, R. Stahlberg, S. Mancuso, J. Vivanco, F. Baluška, E. Van Volkenburgh, Plant neurobiology: an integrated view of plant signalling, Trends Plant Sci. 11(2006), 413-419; R. Stahlberg, Historical Overview on Plant Neurobiology (Review), Plant Signaling\&Behavior 1(2006)1, 6-8; A. Trewavas, Plant behaviour and intelligence, op. cit.

18 Z. Starck, op. cit.

19 Ibidem, 21.

20 A. Trewavas Plant intelligence: Mindless mastery, op. cit. 
mechanical, oxidative and electric signals, peptides, lipids, sugars, wall portions and other complex hydrocarbons. Even anatomically homogenous cells generate extremely different responses to a single signal.

The huge variation in individual cell behaviour can be coordinated in the production of various bodily behaviour. ${ }^{21}$ However, the manner in which plant cells accumulate this large amount of information is not clear. The necessity to try to explain these enigmatic processes was urged, among others, by the physiology and medicine Nobel Prize winner, Barbara McClintock: "A goal for the future could be to determine the extent of knowledge the cell has of itself and how it uses that knowledge in a thoughtful manner when challenged."22 Trewavas indicates three key research issues that refer directly to the challenge posed by Barbara McClintock: "(...) firstly that plant cells may have knowledge of themselves; secondly that they have receive challenges which lead to behavioral changes; finally, that they do so in a manner which implies assessment and intelligent behavior." ${ }^{23}$

\section{PLANT INTELLIGENCE AN EMPIRICALLY BASED BIOPHILOSOPHICAL CONTROVERSY}

Faced with the enormous number of new facts about the complex behaviour of plants, some researchers have begun talking about the intelligence of plants, ignoring the fact that positing an explanation in terms of "intelligence" is exposed to numerous misunderstandings. The concept of "intelligence" is multi-faceted and heterogeneous in both philosophy (where it is used to indicate a way of thinking as well as a mode of action or proceeding) and empirical science. ${ }^{24}$

21 Z. Starck, op. cit.

22 B. McClintock, Nobel lecture 8 December, http://www.nobelprize.org/nobel_prizes/ medicine/laureates/1983/mcclintock-lecture.pdf, 1983, 193 [accessed: 03.03.2016].

23 A. Trewavas, Plant behaviour and intelligence, op. cit., fourth cover.

24 E.g., S. Legg, M. Hutter, A Collection of Definitions of Intelligence, Frontiers in Artificial Intelligence and Applications 157(2007), 17-24. 
Trewavas $^{25}$ defends the thesis that plants can be classified as intelligent organisms, stressing that despite the great number of publications on intelligent behaviour in the world of living organisms, there is no universally accepted definition of intelligence. ${ }^{26}$ As a rule, dictionary definitions of intelligence assume an anthropocentric point of view, claiming that only humans are intelligent. ${ }^{27} \mathrm{It}$ is often claimed that only animals having brains can be smart. This view is simply the

25 A. Trewavas, How plants learn, op. cit.; Idem, Plant intelligence: Mindless mastery, op. cit.; Idem, Aspects of plant intelligence, op. cit.; Idem, Aspects of plant intelligence: an answer to Firn, op. cit., Idem, Green plants as intelligent organisms, op. cit., Idem, Plant intelligence, op. cit., Idem, Plant neurobiology - all metaphors have value, op. cit.

26 Biological perspectives on intelligence include, for instance, species intelligence (J. Schull, Are species intelligent?, Behav. Brain. Sci. 13(1990), 63-108), immunological intelligence (F.T. Vertosick, The Genius within. Discovering the intelligence of every living thing, Harcourt, New York 2002), the intelligent genome (D.S. Thaler, The evolution of genetic intelligence, Science 264(1994), 1698-1699; A. Durrant, The environmental induction of heritable change in Linum, Heredity 17(1962), 27-61; Idem, Unstable genotypes, Phil. Trans. R. Soc. Lond. Ser. B Biol. Sci. 292(1981), 467-474), metabolic intelligence (A. Arkin, J. Ross, Computational functions in biochemical reaction networks, Biophysical Journal 67(1994), 560-578; D. Bray, Protein molecules as computational elements in living cells, Nature 376(1995), 307-312; M. Okamoto, T. Sakai, K. Hayashi, Switching mechanism of a cyclic enzyme system: role as a chemical diode, Biosystems 21(1987), 1-11), and swarm intelligence (E. Bonabeau, C. Meyer, Swarm intelligence, Harvard Business Review, (2001)5, 107-114; E. Bonabeau, G. Theraulaz, Swarm Smarts, Scientific American 282 (2000), 72-79; E. Bonabeau, M. Dorigo, G. Theraulax, Inspiration for optimisation from social insect behavior. Nature 406(2000), 39-42; N.R. Franks, A. Dornhaus, J.P.Fitzsimmons, M. Stevens, Speed versus accuracy in collective decision-making, Proc. R. Soc. Lond. Ser. B Biol. Sci. 270(2003), 2457-2463; T.D. Seeley, The Wisdom of the hive. The social physiology of honey bee colonies, Harvard University Press, Cambridge Mass. - London 1995). As noticed by R. Goodwins: "part of the trouble is that nobody knows what artificial intelligence is. In fact nobody even knows what intelligence is"(R. Goodwins, The machine that wanted to be a mind, ZDNet UK 23(2001)1, http://www. zdnet.com/article/the-machine-that-wanted-to-be-a-mind [accessed: 02.03.2016]). A similar remark is found in $\mathrm{K}$. Warwick: "there are many views about the nature of intelligence but no agreement as to its meaning" (K. Warwick, The quest for intelligence, Judy Piatkus, London 2001, 52).

27 A. Trewavas, Green plants as intelligent organisms, op. cit., 413-419; Idem, Plant intelligence, op. cit., 401-413. 
expression of a specific cerebral "chauvinism", as noted by Vertosick. ${ }^{28}$ The psychologist Shull ${ }^{29}$ recognizes this view as both anthropocentric and as attributing some "vitalistic" quality to nerve cells. ${ }^{30}$

The idea that plants are intelligent organisms has met opposition by a large group of researchers. ${ }^{31}$ Some of them have expressed their critical attitude to this new field of research, which they claim promotes controversial ideas in plant studies. They find the suggestion that plants have nerves, synapses, or something analogous to the brain located somewhere in the roots, unjustified. More generally, they criticized attempts to classify plants as intelligent beings. They believed that the term "intelligence" may obscure a proper understanding of the life processes of plant organisms rather than explain them. According to Firn ${ }^{32}$ the implementation of a new term for certain plant life processes is unnecessary and does not contribute anything. He sees no need to use the term "intelligence" as a substitute for "adaptive responses of plants". Further controversy to the already heated debate on plant intelligence was triggered in 2005, when the new field of plant neurobiology was established, quickly gaining many supporters as well as opponents. Green plants are treated by plant neurobiologists as intelligent organisms endowed with memory, which allows them to learn and use stored information to implement a "life strategy" ${ }^{33}$ Despite the critical remarks, it should be clearly said

28 F.T. Vertosick, op. cit.

29 J. Shull, op. cit.

30 A. Trewavas, Green plants as intelligent organisms, op. cit.

31 See R. Firn, Plant Intelligence: an Alternative Point of View, Annals of Botany 93(2004), 345-351; A. Alpi et al. Plant neurobiology: no brain, no gain?, Trends Plant Sci. 12(2007)4, 135-136.

32 R. Firn, op. cit.

33 Cf. E.D. Brenner, R. Stahlberg, S. Mancuso, J. Vivanco, F. Baluška, E. Van Volkenburgh, Plant neurobiology: an integrated view of plant signalling, op. cit.; E.D. Brenner, R. Stahlberg, S. Mancuso, F. Baluška, E. Van Volkenburgh, Response to Alpi, et al.: plant neurobiology: the gain is more than the name, op. cit.; A. Trewavas, Plant neurobiology - all metaphors have value, op. cit.; Z. Starck, op. cit. 
that the introduction of the term "intelligence" in botany further directed the attention of researchers towards some holistic phenomena associated with plant functioning. As recorded by the International Laboratory for Plant Neurobiology $y^{34}$, numerous pieces of research ${ }^{35}$ have confirmed that plants have a very well organized sensory system, which allows them to explore the environment efficiently and to react rapidly to potentially dangerous circumstances. Below and above ground, plants are aware of the space surrounding them. Such responsiveness is indeed necessary to perform appropriate actions in response to environmental stimuli. Plants have memory and are capable to learn, solve problems and make decisions. It is accepted that the specific plant behaviour that look very much like animal learning, memory, decision-making, and intelligence deserves to be classified according to these latter categories.

In light of these controversies, it is very important to try to systematize the terminology that is used to describe the behaviour of living organisms. In the Polish literature such terminology was introduced, among others, by Lenartowicz and Koszteyn, whose work will constitute a reference point here. ${ }^{36}$ As a starting point, it is important

34 http://www.linv.org/wp-content/uploads/2014/10/brochure_linv.pdf [accessed: 10.03.2015].

35 Relevant publications: E.D. Brenner, et al., Plant neurobiology: an integrated view of plant signalling, op. cit.; E. Masi, M. Ciszak, G. Stefano, L. Renna, E. Azzarello, C. Pandolfi, S. Mugnai, F. Baluška, F.T. Arecchi, S. Mancuso, Spatiotemporal dynamics of the electrical network activity in the root apex, Proceedings of the National Academy of Sciences 106(2009)10, 4048-4053; F. Baluška et al, Root apex transition zone: a signalling-response nexus in the root, op. cit., 402-408; F. Baluška et al, Swarm intelligence in plant roots, op. cit., 682-683; M. Gagliano, S. Mancuso, D. Robert, Towards understanding plant bioacoustics, Trends in plant science 17(2012)6, 323-325; M. Ciszak, D. Comparini, B. Mazzolai, F. Baluška, F.T. Arecchi, F. Tito Arecchi, T. Vicsek, S. Mancuso, Swarming behavior in plant roots, PLoS One 7(2012)1, 1-7; M. Gagliano, M. Renton, M. Depczynski, S. Mancuso, Experience teaches plants to learn faster and forget slower in environments where it matters, Oecologia (2014), 1-10.

36 E.g.: P. Lenartowicz, Racjonalność ducha czy życia?, Kwartalnik Filozoficzny 23(1995)2, 87-98; J. Koszteyn, P. Lenartowicz, Biological adaptation: dependence or independence from environment?, Forum Philosophicum, Fac. Philos. SJ, 2(1997), 71-102; J. Koszteyn, P. 
to define certain minimal but fundamental conditions that make it possible to correctly approach plant dynamics. The following minimal conditions should be accepted as "necessary":

- having biological tools,

- being able to use them,

- being able to orientate themselves and the structures of their own bodies in the environment. ${ }^{37}$

As noted by Koszteyn, "most of the structures of the body of living creatures (humans, animals, plants, bacteria) are biological tools of different size - from the molecular to the anatomical. Most of the tools are molecular biological machinery such as ATPase, proton motor Escherichia coli, ribosomes, proteasomes." ${ }^{38}$ The sine qua non condition, without which no living creature could have any selective effect on their surrounding environment is the ability to orientate in it. It is hard to imagine orientation according to environmental cues without at least a rudimentary ability to orientate the position of body structures, conceived primarily as biological tools. It is the orientation and selective use of inbuilt biological tools that allow living beings to manipulate material objects. Koszteyn writes: "Manipulation is one of the types of selective, coordinated and integrated action, that both in everyday language and science, we call behavior of living forms". ${ }^{39}$ In his analysis of the photoadaptive dynamics of mugeotia, Koszteyn stresses that the behavior of this chlorophyte "is an illustration of the universal tendency in the world of living beings to rely on some form of dynamic response, to actively oppose the unfavourable influences

Lenartowicz, Wyjściowe przesłanki teorii życia biologicznego, in: W poszukiwaniu istoty życia, eds. G. Bugajak, A. Latawiec, Wydawnictwo Uniwersytetu Kardynała Stefana Wyszyńskiego, Warszawa 2005, 25-40; J. Koszteyn, Actio immanens - a fundamental concept of biological investigation, Forum Philosophicum. Fac. Philos. Ignatianum 8(2003), 81-120; J. Koszteyn, Życie a orientacja w rzeczywistości przyrodniczej, WAM, Kraków 2005.

37 J. Koszteyn, Życie a orientacja w rzeczywistości przyrodniczej, op. cit., 122.

38 Ibidem, 123.

39 Ibidem, 123-124. 
of the environment. Such a trend will not be met in the mineral world; this is a feature of life - the attribute of living beings. ${ }^{30}$ After observing the behaviour of this chlorophyte (mugeotia), which uses environmental light energy, we have noted three similar trends in its internal locomotion structures:

- the tendency to rest when the optimum number of photons reaches the photosynthetic apparatus, at which point the locomotor system does not display any activity,

- the tendency to explore (i.e., the chloroplast is positioned perpendicular to the light) occurs when the energy level reaching the chloroplast decreases,

- avoidance behaviour (i.e., the chloroplast is positioned with the edge towards the incident light) occurs when the energy level increases too quickly.

The body of the mugeotia has a very effective and selective tool for measuring (monitoring) parameters such as light intensity. This measuring tool is both very precise and very resistant to relatively large fluctuations in the levels of registered parameters. It should be emphasized that the mere possession of measuring (monitoring) tools is not sufficient to explain the phenomenon of protective adaptation. Equally necessary is a suitably shaped system of internal transport, which provides the "control" system with the appropriate forms of energy. As emphasized by Koszteyn, all these systems are not merely a purely logical theoretical postulates; their cellular physiology and structure have also been observed and described. ${ }^{41}$

The above discussion shows that concepts such as orientation, selection, and manipulation seem more adequate to describe the behaviour of plants than a notion such as "intelligence", which is weighed down with ambiguity. ${ }^{42}$

40 Ibidem, 143.

41 Ibidem.

42 See P. Lenartowicz, Racjonalność ducha czy życia?, op. cit., 812. 


\section{CONCLUSION}

Despite some important differences in the views defended, current research shows the remarkable progress in our knowledge of plant biology. The source of the debates concerning the intelligence of plants are empirical observations pointing to the fact that the dynamic behaviour of plants is not only selective and economical, but also holistic. ${ }^{43}$ Such a selectivity, efficiency and holism are now being investigated at the deeper level of tissue and organ structures and even further at the level of biochemical processes inside individual living cells. ${ }^{44}$ Integral components of biological dynamics are the orientation of environmental features and the states produced by bodily structures, both internal and external. Just like all other organisms, plants feature processes manufacturing biological tools and mechanisms, using biological tools, and orientating themselves within the environment and the body's own structures. ${ }^{45}$ The progress in plant behaviour research suggests that the notion of an absolute integration of plants with specific environmental parameters should be revised. To a certain extent, plants are capable of active adaptation to changing conditions. They can manipulate the use of acquired energy. Plants can also actively seek energy resources and change their form. Integration and development would be impossible without the selective extraction of raw material and energy from the environment. Raw material must be found and selectively absorbed. Observations show that the process of finding raw materials is economical, which presupposes the body's ability to orientate itself according to the physical features of the environment. If we consider orientation to be

43 See e.g. E.D. Brenner et al., Biological adaptation: dependence or independence from environment?, op.cit.; E.D. Brenner et al, Plant neurobiology: an integrated view of plant signalling, op. cit.; Z. Starck, op. cit.; A. Trewavas, Plant behaviour and intelligence, op. cit.

44 Cf. P. Lenartowicz, Racjonalność ducha czy życia?, op. cit.

45 J. Koszteyn, P. Lenartowicz, Biological adaptation: dependence or independence from environment?, op. cit. 
an elementary, cognitive act, we should also acknowledge that cognitive processes do not occur exclusively in animals equipped with a nervous system. As shown above, in recent years extremely selective and efficient orientation processes have been discovered in plants. Their tendency to orientate in the environment results from the construction of specific structures (sensors) that monitor changes in certain selected parameters of the environment. ${ }^{46}$

Summing up, current empirical research into the physiology and behaviour of plants seems to shows that the traditional division of the living world proposed by Aristotle, according to which plants are devoid of sensory capacities, requires some adjustments. ${ }^{47}$ Growing consensus on the fact that plants show some rudimentary cognitive processes has implications for different fields of science. The epistemological controversy, generated by a better understanding of plant behaviour, has not so far been widely considered by philosophers. Notable exceptions to this lack of interest can be found in the context of interdisciplinary research projects, including for instance the recent attempt to establish the philosophy of plant neurobiology, which already has its own "manifesto." This document draws a road map for establishing and developing a new field of research situated between the philosophy of cognitive science and plant neurobiology. The philosophy of plant neurobiology has introduced new challenges, suggested new directions for empirical research and provided us with explanations and a rule-based methodology that can integrate all research seeking intelligence in plants. ${ }^{48}$ Finally, we can ask (in noting given the complex dynamics of plant behaviour), whether it is

46 Ibidem.

47 See J. Koszteyn, Actio immanens - a fundamental concept of biological investigation, op. cit.

48 Cf. P. Calvo, The philosophy of plant neurobiology: a manifesto, http://www.um.es/ documents/2103613/2107123/MANIFESTO_PLANT+NEUROBIOLOGY+AND+ITS+PHILO SOPHY.pdf [accessed: 29.02.2016]. 
reasonable to accept (as a growing number of researchers are inclined to claim) that intelligence is a feature present in all living organisms?

\section{BIBLIOGRAPHY}

Advances in Plant Physiology, ed. P.C. Trivedi, I K International Publishing House, New Delhi 2006.

Alpi A., Amrhein N., Bertl A., Blatt M.R., Blumwald E., Cervone F., Dainty J., De Michelis M.I., Epstein E., Galston A.W., Goldsmith M.H., Hawes C., Hell R., Hetherington A., Hofte H., Juergens G., Leaver C.J., Moroni A., Murphy A., Oparka K., Perata P., Quader H., Rausch T., Ritzenthaler C., Rivetta A., Robinson D.G., Sanders D., Scheres B., Schumacher K., Sentenac H., Slayman C.L., Soave C., Somerville C., Taiz L., Thiel G., Wagner R., Plant neurobiology: no brain, no gain?, Trends Plant Sci. 12(2007)4, 135-136.

Aristotle, De Anima, tr. by R.D. Hicks, https://archive.org/details/ aristotledeanima005947mbp

Arkin A., Ross J., Computational functions in biochemical reaction networks, Biophysical Journal 67(1994), 560-578.

Baluška F., Lev-Yadun S., Mancuso S., Swarm intelligence in plant roots, Trends in Ecology \& Evolution 25(2010), 682-683.

Baluška F., Mancuso S., Volkmann D., Barlow P., Root apices as plant command centres: the unique 'brain-like' status of the root apex transition zone, Biologia 59(2004)59/Suppl. 13, Bratislava, 7-19.

Baluška F., Mancuso S., Volkmann D., Barlow P.W., Root apex transition zone: a signalling-response nexus in the root, Trends in plant science 15(2010)7, 402-408.

Baluška F., Volkmann D., Hlavacka A., Mancuso S., Barlow P.W., Neurobiological View of Plants and Their Body Plan, in: Communication in Plants: neuronal aspects of plant life, eds. F. Baluška, S. Mancuso, D. Volkmann, Springer, Berlin 2006, 19-35.

Bennet-Clark T.A., Ball N.G., The diageotropic behaviour of rhizomes, Journal of Experimental Botany 2(1951), 169-203.

Bonabeau E., Dorigo M., Theraulax G., Inspiration for optimisation from social insect behavior. Nature 406(2000), 39-42.

Bonabeau E., Meyer C., Swarm intelligence, Harvard Business Review, (2001)5, 107-114.

Bonabeau E., Theraulaz G., Swarm Smarts, Scientific American 282 (2000), 72-79.

Bray D., Protein molecules as computational elements in living cells, Nature 376(1995), 307-312. 
Brenner E.D., Stahlberg R., Mancuso S., Baluška F., Van Volkenburgh E., Response to Alpi, et al.: plant neurobiology: the gain is more than the name, Trends Plant Sci., 12(2007), 285-286.

Brenner E.D., Stahlberg R., Mancuso S., Vivanco J., Baluška F., Van Volkenburgh E., Plant neurobiology: an integrated view of plant signalling, Trends in plant science 11(2006)8, 413-419.

Brenner E.D., Stahlberg R., Mancuso S., Vivanco J., Baluška F., Van Volkenburgh E., Plant neurobiology: an integrated view of plant signalling, Trends Plant Sci. 11(2006), 413-419.

Calvo P., The philosophy of plant neurobiology: a manifesto, http://www.um.es/ documents/2103613/2107123/MANIFESTO_PLANT+NEUROBIOLOGY+AND+ITS+PHILOSOPHY.pdf.

Chamovitz D., What a plant knows. A Field Guide to the Senses, Scienific American/ Farrar, Straus and Giroux, New York 2012.

Charnov E.L., Optimal foraging, the marginal value theorem, Theoretical Population Biology 9(1976), 129-136.

Christie J.M., Murphy A.S., Shoot phototropism in higher plants: New light through old concept,. American Journal of Botany 100(2013)1, 35-46.

Ciszak M., Comparini D., Mazzolai B., Baluška F., Arecchi F.T., Tito Arecchi F., Vicsek T., Mancuso S., Swarming behavior in plant roots, PLoS One 7(2012)1, $1-7$.

Curry G.M., Phototropism, in: The physiology of plant growth and development, ed. M.B. Wilkins, McGraw-Hill, London 1969, 243-273.

Cvrčková F., Lipavská H., Žárský V., Plant intelligence, Why, why not or where?, Plant Signaling \& Behavior 4(2009)5, 394-399.

Durrant A., The environmental induction of heritable change in Linum, Heredity 17(1962), 27-61.

Durrant A., Unstable genotypes, Phil. Trans. R. Soc. Lond. Ser. B Biol. Sci. 292(1981), 467-474.

Evans J.P., Cain M.L., A spatially explicit test offoraging behaviour in a clonal plant, Ecology 76(1995), 1147-1155.

Firn R., Plant Intelligence: an Alternative Point of View, Annals of Botany 93(2004), 345-351.

Fizjologia roślin, ed. J. Kopcewicz, S. Lewak, PWN, Warszawa 2002.

Franco M., The influence of neighbours on the growth of modular organisms with an example from trees, Phil. Trans. R. Soc. Lond. Ser. B Biol. Sci. 313(1986), 209-225. 
Franks N.R., Dornhaus A., Fitzsimmons J.P., Stevens M., Speed versus accuracy in collective decision-making, Proc. R. Soc. Lond. Ser. B Biol. Sci. 270(2003), 2457-2463.

Gagliano M., Mancuso S., Robert D., Towards understanding plant bioacoustics, Trends in plant science 17(2012)6, 323-325.

Gagliano M., Renton M., Depczynski M., Mancuso S., Experience teaches plants to learn faster and forget slower in environments where it matters, Oecologia (2014), 1-10.

Gilroy S., Trewavas A., Signal processing and transduction on plant cells: the end of the beginning?, Nature Reviews Molecular Cell Biology 2(2001), 307-314.

Goh C.H., Nam H.G., Park Y.S., Stress memory in plants: a negative regulation of stomatal response and transient induction of rd22 gene to light in abscisic acid-entrained Arabidopsis plants, Plant J. 36(2003)2, 240-255.

Goodwins R., The machine that wanted to be a mind, ZDNet UK 23(2001)1, http:// www.zdnet.com/article/the-machine-that-wanted-to-be-a-mind.

Goyal A., Szarzynska B., Fankhauser C., Phototropism: at the crossroads of light-signaling pathways, Cell (2012), 1-9.

Gregory P.J., Plant Roots: Growth, Activity and Interactions with the Soil, Wiley-Blackwell, Oxford 2006.

Huber-Sannwald E., Pryce D.A., Caldwell M.M., Perception of neighbouring plants by rhizomes and roots: morphological manifestations of a clonal plant, Can. J. Bot. 75(1997), 2146-2157.

Hutchins M.J., Kroon H. de, Foraging in plants: the role of morphological plasticity in resource acquisition, Advances in Ecological Research 25(1994), 159-238.

Jones M., Harper J.L., The influence of neighbours on the growth of trees. I. The demography of buds in Betula pendula, Proceedings of the Royal Society London B 232(1987), 1-8.

Jones M., Harper J.L., The influence of neighbours on the growth of trees. II. The fate of buds on long and short shoots in Betula pendula, Proceedings of the Royal Society London B 232(1987), 19-33.

Karpiński S., Szechyńska-Hebda M., Secret life of plants. From memory to intelligence, Plant Signal. Behav. 5(2010)11, 1391-1394.

Kelly C.K., Resource choice in Cuscuta europea, Proc. Natl. Acad. Sci. U. S. A. 89(1992), 12194-12197.

Kelly C.L., Plant foraging: a marginal value model and coiling response in Cuscuta subinclusa, Ecology 71(1990), 1916-1925.

Knight H., Brandt S., Knight M.R., A history of stress alters drought calcium signalling pathways in Arabidopsis, Plant Journal 16(1998)6, 681-687. 
Koszteyn J., Actio immanens - a fundamental concept of biological investigation, Forum Philosophicum. Fac. Philos. Ignatianum 8(2003), 81-120.

Koszteyn J., Lenartowicz P., Biological adaptation: dependence or independence from environment?, Forum Philosophicum, Fac. Philos. SJ, 2(1997), 71-102.

Koszteyn J., Lenartowicz P., Wyjsciowe przestanki teorii życia biologicznego, in: $W$ poszukiwaniu istoty życia, eds. G. Bugajak, A. Latawiec, Wydawnictwo Uniwersytetu Kardynała Stefana Wyszyńskiego, Warszawa 2005, 25-40.

Koszteyn J., Życie a orientacja w rzeczywistości przyrodniczej, WAM, Kraków 2005. Legg S., Hutter M., A Collection of Definitions of Intelligence, Frontiers in Artificial Intelligence and Applications 157(2007), 17-24.

Lenartowicz P., Elementy filozofii zjawiska biologicznego, WAM, Kraków 1986.

Lenartowicz P., Racjonalność ducha czy życia?, Kwartalnik Filozoficzny 23(1995)2, 87-98.

Liscum E., Phototropism: Mechanisms and Outcomes, Arabidopsis Book (2002), 1-21. Mac Donald S.E., Leiffers V.J., Rhizome plasticity and clona foraging of Calamagrostis canadensis in response to habitat heterogeneity, J. Ecol. 81(1993), 769-776.

Mancuso S., Viola A., Brilliant Green. The Suprising History and Science of Plant Intelligence, Island Press, Washington 2015.

Masi E., Ciszak M., Stefano G., Renna L., Azzarello E., Pandolfi C., Mugnai S., Baluška F., Arecchi F.T., Mancuso S., Spatiotemporal dynamics of the electrical network activity in the root apex, Proceedings of the National Academy of Sciences 106(2009)10, 4048-4053.

McClintock B., Nobel lecture 8 December, http://www.nobelprize.org/nobel_prizes/ medicine/laureates/1983/mcclintock-lecture.pdf, 1983, 180-199.

McConnaughay K.D.M., Bazzaz F.A., Is physical space a soil resource, Ecology 72(1991), 94-103.

McConnaughay K.D.M., Bazzaz F.A., The occupation and fragmentation of space:consequences of neighbouring roots, Functional Ecology 6(1992), 704-710.

McNickle1 G.G., Cahill J.F.Jr., Plant root growth and the marginal value Thorem, PNAS 106(2009)12, 4747-4751.

Novoplansky A., Cohen D., Sachs T., How Portulaca seedlings avoid their neighbours, Oecologia 82(1990), 490-493.

Okamoto M., Sakai T., Hayashi K., Switching mechanism of a cyclic enzyme system: role as a chemical diode, Biosystems 21(1987), 1-11.

Plant Physiology, eds. L. Taiz, E. Zeiger, Sinauer Associates, Inc., Publ., Sunderland 1998. 
Rodin L.E., Bazilevich N.I., Rozov N.N., Productivity of the World's Main Ecosystems, in: Productivity of World Ecosystems, eds. D.E. Reichle, et. al., National Academy of Science, Washington D.C (1975), 13-26.

Roig-Villanova I., Martínez-García J.F., Plant Responses to Vegetation Proximity: A Whole Life Avoiding Shade, Frontiers in Plant Science 7(2016), Article 236, $1-10$.

Salzman A.G., Habitat selection in a clona plant, Science 228(1985), 603-604.

Schull J., Are species intelligent?, Behav. Brain. Sci. 13(1990), 63-108.

Seeley T.D., The Wisdom of the hive. The social physiology of honey bee colonies, Harvard University Press, Cambridge Mass. - London 1995.

Stahlberg R., Historical Overview on Plant Neurobiology (Review), Plant Signaling\&Behavior 1(2006)1, 6-8.

Starck Z., Roślina in vivo - kunszt funkcjonalności wzorowanej na procesach zachodzacych u zwierząt, Wiad. Botan. 55(2011)1-2, 5-21.

Stoll P., Schmid B., Plant foraging and dynamic competition between branches of Pinus sylvestris in contrasting light environments, Journal of Ecology 86(1998)6, 934-945.

Sultan S.E., Phenotypic plasticity for plant development function and life history, Trend Plant Sci. 5(2000), 537-542.

Szkutnik D., Kupczak R., The Aristotelian concept of psyché trophica and contemporary attempts to conceptualize the functioning of plants holistically, Biocosmology- Neo-Aristotelism 5(2015)2, 186-195.

Thaler D.S., The evolution of genetic intelligence, Science 264(1994), 1698-1699.

Thellier M., Despiez M.O., Champagnat P., Kergosien Y., Do memory processes occur also in plants?, Physiologia Plantarum 56(1982), 281-284.

Trewavas A., Aspects of plant intelligence, Ann. Bot. 92(2003), 1-20.

Trewavas A., Aspects of plant intelligence: an answer to Firn, Ann. Bot. 93(2004), 353-357.

Trewavas A., Green plants as intelligent organisms, Trends Plant Sci. 10(2005), 413-419.

Trewavas A., How plants learn, Proc. Natl. Acad. Sci. USA 96(1999), 4216-4218. Trewavas A., Plant behaviour and intelligence, Oxford University Press, Oxford 2014.

Trewavas A., Plant intelligence, Naturwissenschaften 92(2005), 401-413.

Trewavas A., Plant intelligence: Mindless mastery, Nature 415(2002), 841.

Trewavas A., Plant neurobiology - all metaphors have value, Trends Plant Sci. 12(2007), 231-233.

Vertosick F.T., The Genius within. Discovering the intelligence of every living thing, Harcourt, New York 2002. 
Warwick K., The quest for intelligence, Judy Piatkus, London 2001.

Weaver J.E., Root development of field crops, McGraw Hill, New York 1926, https:// soilandhealth.org/wpcontent/uploads/GoodBooks/Root\%20Development\%20 of $\% 20$ Field\%20Crops.pdf.

Whippo C.W., Hangarter R.P., Phototropism: Bending towards Enlightenment, Plant Cell. 18(2006)5, 1110-1119.

\author{
RAFAŁ KUPCZAK \\ rafalkupczak@wp.pl \\ Akademia Ignatianum w Krakowie, Instytut Filozofii \\ Kopernika 26, 31-501 Kraków
}

DOI: $10.21697 /$ spch.2017.53.2.04 